Victor Aulin - Oleg Lyashuk - Olexiy Pavlenko - Denis Velykodnyi - Andrii Hrynkiv

Sergii Lysenko - Dmytro Holub - Yuriy Vovk - Volodymyr Dzyura - Mariana Sokol*

\title{
REALIZATION OF THE LOGISTIC APPROACH IN THE INTERNATIONAL CARGO DELIVERY SISTEM
}

Fierce rivalry in the transport market raises serious reassessment and implementation of new approaches to logistics companies and trade enterprises in marketing of goods. To maintain the volume of domestic sales and output to the external one, producers and trading firms are forced to expand their trade and economic relations that occur in other regions. The integration of the world economy and policy orientation of foreign trade to free trade greatly simplify the task of setting up the free trade and economic connections, but the question is how quickly and efficiently, with the least costs, it is necessary to put the goods in the right region to the customer.

In modern market conditions, international container transportation of goods between Ukraine and the European Union countries has a prospect of development, as each year the number of orders in transport and logistics enterprises increases. After analyzing the status of orders, the problem has been detected and widely connected with the method of organization of container cargo delivery in international communication and the formation of rational technology of serviced. To solve this problem a method of logistic approach to the system of containers transportation has been proposed based on the cybernetic model "white box". The initial stage of its implementation involves formation of the limitation system of input parameters and factors that are consistent with the needs of the customer firm and the company performing transportation. Ten alternative order services schemes, each of which takes into account the possible combinations of operations, has been proposed.

Based on the company "Inter Trans Logistic“, which serviced the order of the company „Agricultural Holding August" for the transportation of rape seeds, 10 tons of corn on demand and a portion of sunflower oil 20,000 liters, according to their applications for transportation, a logistic approach using a cybernetic model "white box" has been implemented. Based on the mathematical models of changes in the total costs of the international container cargo shipping company of the customer, it has been shown that the maximum expenses are occurring in the implementation of the scheme 1 service order. In that case, the costs have been in the range of 848.72 to 7455.41 US \$, according to a certain series of experiments. Based on the condition of the minimum cost function for container transportation, scheme 1 has been chosen as limiting scheme of service order against which the assessment carried out changes of the total costs in the implementation of other schemes. In percentage display according to Scheme 1, the following percentage intervals have been deducted for the reduction of sales costs: Scheme 2 - 12.70 to 34.98\%; Scheme 3 - 2.93 to 12.00\%; Scheme 4 - 2.06 to 10.88\%; Scheme 5 - 1.69 to 4.25\%; Scheme 6 - 0.87 to 3.28\%; scheme 7 - 0.97 to 2.58\%; Scheme 8 - 1.64 to 4.45\%; Scheme 9 - 2.66 to $11.77 \%$; scheme $10-2.33$ to $9.94 \%$.

The results of experimental studies indicate that when the proposed methodology of the logistic approach, using the "white box" based on the company "Inter Trans Logistic" to international container transportation of goods in relation to the application of the company „Agricultural Holding August" for transportation, the scheme 2 sequence of transport operations has been effective. In its realization the costs for 12.70 to $34.98 \%$ has been decreased in comparison with the marginal service scheme.

Keywords: logistic approach, transportation technology, container international traffic

\section{Introduction}

Transport is a branch of production that provides society vital needs in goods transportation, and is a part of the infrastructure production. By providing the transportation goods, transport makes a significant contribution to development of foreign economic, scientific, technical and cultural, sports and other connections of Ukraine, mainly with the European Union countries. According to this, there is an increasing tendency of demands for international transport services, both in terms of volume and nomenclature [1].
The over-saturation of the market, consumer dictation in the market and rigid competition cause serious difficulties for producers, trading and sales enterprises in the sale of goods. To save sales volumes, manufacturers and trading firms are forced to go on expansion sales at the expense of entering markets that are located in other regions. And while the world economy integration and countries foreign trade policy orientation to free trade greatly simplify this task, so the following question has been raised: how quickly and efficiently, with the least costs, it is necessary to put the goods on the market [2].

\footnotetext{
* ${ }^{1}$ Victor Aulin, ${ }^{2}$ Oleg Lyashuk, ${ }^{3}$ Olexiy Pavlenko, ${ }^{1}$ Denis Velykodnyi, ${ }^{1}$ Andrii Hrynkiv, ${ }^{1}$ Sergii Lysenko, ${ }^{1}$ Dmytro Holub, ${ }^{2}$ Yuriy Vovk, ${ }^{2}$ Volodymyr Dzyura, ${ }^{4}$ Mariana Sokol

${ }^{1}$ Department of Maintenance and Repair of Machines, Central Ukrainian National Technical University, Kirovograd, Ukraine

${ }^{2}$ Department of Automobiles, Ternopil Ivan Puluj National Technical University, Ukraine

${ }^{3}$ Department of Transport Technologies, Kharkiv National Automobile and Road University, Ukraine

${ }^{4}$ Foreign Languages Department, Ternopil State Medical University, Ukraine

E-mail: vovkyuriy@ukr.net
} 
Nowadays, in the global market, the process of goods delivery is associated with the process of performing a series of works, operations and services, the complex of which will ensure the efficient goods distribution. In such a situation, transport companies are faced with the task of using efficient tools, developing methods and procedures for handling orders for any cargo owner with the most need for quality services. There is a need to develop a rational technology for servicing orders, while the delivery of goods in containers in international traffic has been organized.

The relevance of international container transportation has been increased [3]. This is evidenced by the existence and creation of new large, modern companies that are specialized precisely in this type of cargo delivery organization. They compete with each other by offering customers the best, more economical, faster, better ways to handle orders and deliver in international containers, and the ability to deliver goods to anywhere in the world. That is why such process necessitates development of the efficient container transportation technologies.

Container transportation between Ukraine and the European Union countries has been recognized as the most modern and high-quality way of international transportation. That allowed reducing the share of transport component in the final price of the goods from $2 \%$ to $11 \%$. The selection of rational order service technology and, as a result, the reduction of shipping costs is a priority task for many companies whose main goal is, logistically, to provide the right product in the right amount, quality and at the right time [4]. The use of containers increases transportation efficiency, because the costs associated with the movement, storage and handlings of goods are significantly reduced.

New representative offices of world large companies continue to open in Ukraine. Thus, in January 2017 it became known that the international operator FM Logistic began to work in the segment of the sea container traffic in Ukraine. The third largest company had been opened in Odessa. The company provides multimodal services, interacts with port operators, ship-owners and container lines, customs, railways, carriers to create a single chain of the cargo delivery.

In the first half of 2018, container terminals in Ukraine processed 340155 TEU. It is $4.7 \%$ more than the volume processed in the same period of 2017. Growth, compared to previous year's indexes, shows that transshipment increased by $24.4 \%$, of course, it is not so impressive, but encouraging the pace of development and stability.

The developed system solutions in container handling at container terminals allowed improving the efficiency of production management using modern technologies implementation in the ports of China [5-9]. One of the important issues in this system is the return of empty containers, which is solved by using solutions derived from developed gravity models [10]. In addition, the study [10] proposes an effective solution for the container capacity and the container terminal area.

In the international cargo delivery system, rational construction of the port infrastructure, container terminal and adjacent areas is very important, therefore, to determine the optimal configuration of the location, a two-level programming system was used. This system took into account the container movement in time and allowed to determine the shipping costs with the maximum positive effect for the operator [11].

Article [12] presents a new advanced solution for handling the container terminals system. The process of container terminal manufacturing operations has been described according to workflow and Data Flow Diagram (DFD). The integrity and reliability of the new system using the analysis of the Petri Net has been proven. At the same time, the new solution of the problem is to rebuild the logistic processes that have low costs, high quality, greater flexibility, quick and reasonable response to the entire production system of the terminal.

The authors of the article [13] focus on modeling of the products chain supply. However, the subspace identification methods can be used to characterize relations between some parameters of the supply system. This can be useful if the internal structure of the system was complicated. The supply chains can be identified and modeled by deterministic models of linear states space. The accuracy of the identified model reflects the relationship between certain system parameters and their sensitivity estimates [14-17].

After the oil crisis, Japanese "Just-in-Time" logistics systems have been created at long distances of mutual cooperation between the manufacturer of cars, spare parts suppliers, their logistic subsidiaries and third-party logistics suppliers [18].

Processes and operations in goods delivery can be tested, depending on acceptable methods and approaches for cybernetic models "black, white and gray boxes" [19].

In order to protect the critical data and cryptographic keys, drones' delivery has been provided based on developed methodology using the cybernetic model of the "white box" [20]. Experimental results showed that the proposed methodology had been economically efficient and suitable for supply systems with limited resources. Economic grounds for logistics operations are grounded in the works of Petraska et al. [21], Gajewska and Zimon [22], Agbelie [23], Alghaffari, Nguyen, and Chen [24].

In modern market conditions, international container transportation of goods between Ukraine and EU countries has a development perspective, as each year the number of orders has been increased to the address of transport and transportlogistics enterprises. The revealed found the problem associated with the method of organization of the container cargo delivery in international traffic and the formation of rational technology service orders based on cybernetic model of the «white box».

The aim of the study is to develop a methodology for service orders rational technology formation into the organization of goods delivery in containers in international traffic with minimal costs based on the logistic approach of the transportation system using the cybernetic model "white box". The object of research the process of service orders in the organization of goods delivery in containers in international traffic.

\section{Materials and methods}

The general scheme of service orders in the organization of container goods delivery in international traffic between Ukraine and the European Union countries may include a lot of main operations using different types of transport (road, rail, sea). 


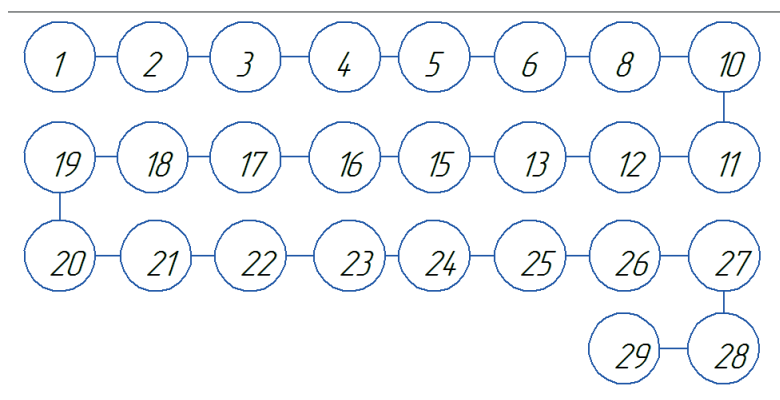

Figure 1 Set and structure of operations according to cargo delivery technology as per scheme I

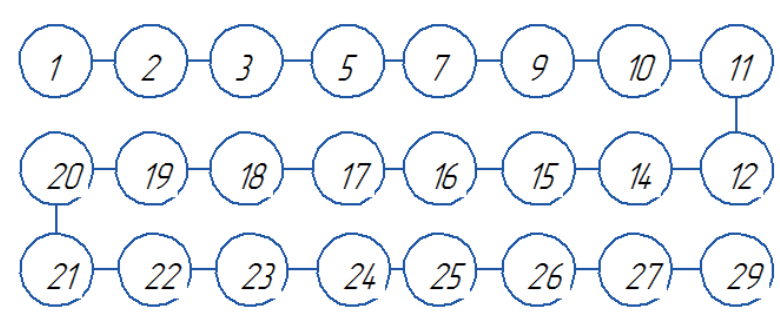

Figure 2 The sequence of operations as per scheme 2

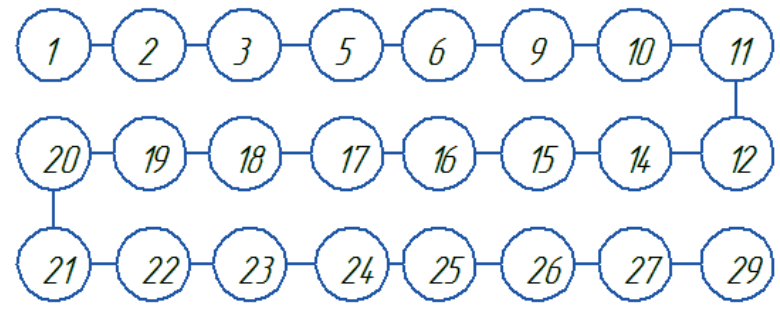

Figure 3 The sequence of operations as per scheme 3

As practice shows, in terms of economic considerations, the combination of different modes of transport is usually used.

To minimize the total shipping costs, the task is to select a set of certain operations, taking into account the requirements of the customer serviced.

The schemes of service orders in the organization of goods delivery in containers in international traffic are formed from the list of operations:

1 - Receipt of an application for transportation from a potential client;

2 - Specification of departure and destination ports;

3 - Selection of appropriate container and determination of its availability;

4 - Search for container among partner companies;

5 - Selection of the type of a vehicle for transportation of goods;

6 - Determination of appropriateness of the auto transport usage;

7 - Determination expediency of the rail transport usage;

8 - Search for transport vehicles among their own;

9 - Vehicle rental in partner's firms;

10 - Identification and search of loading and unloading mechanisms;

11 - Choosing customs brokerage office;

12 - Choosing port delivery scheme;

13 - Determination of reasonability of the auto transport in the destination country;

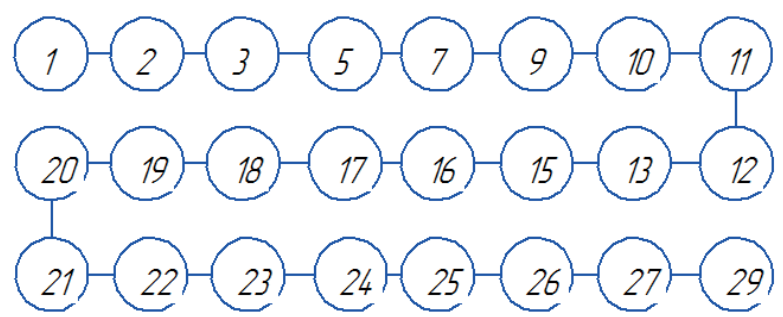

Figure 4 The sequence of operations as per scheme 4

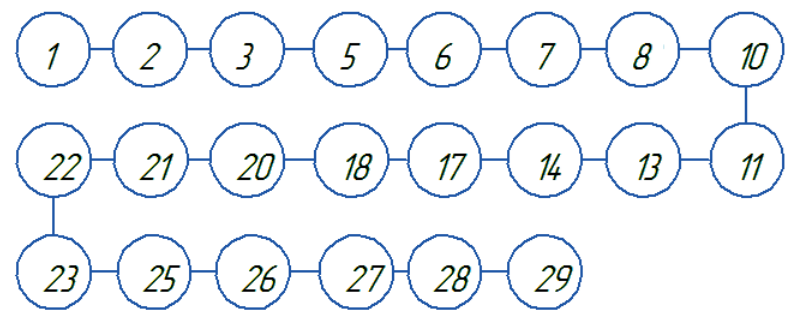

Figure 5 The sequence of operations as per scheme 5

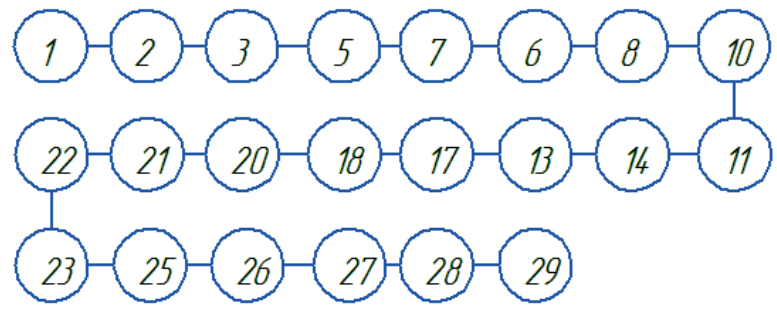

Figure 6 The sequence of operations as per scheme 6

14 - Determination of reasonability of the rail transport in the destination country;

15 - Agreement with the client goods delivery costs;

16 - Contract execution with the contractors and financialpayment, shipping documents;

17 - Supply container and vehicle under load;

18 - Container movement to the terminal;

19 - Transfer and storage of the cargo at the port terminal;

20 - Transfer and overload of the container on the vessel;

21 - Vessel movement to the territory of a foreign state;

22 - Goods transferring into the terminal of the port and unloading the container from the vessel;

23 - Customs clearance in the port;

24 - Storage at the terminal territory;

25 - Vehicle delivery and container loading;

26 - Inside vehicle container movement to its destination;

27 - Unloading the container from the consignee's vehicle;

28 - Cargo unloading outside the container;

29 - Transfer to the recipient.

Ten alternative order schemes have been offered (Figures 1-10), each of which takes into account possible combinations of operations. Thus, for example, the first scheme (Figure 1) has the following features: the transport enterprise does not have its own containers, transport for containers transportation to the port is automobile, there is an own transport vehicle, transportation 


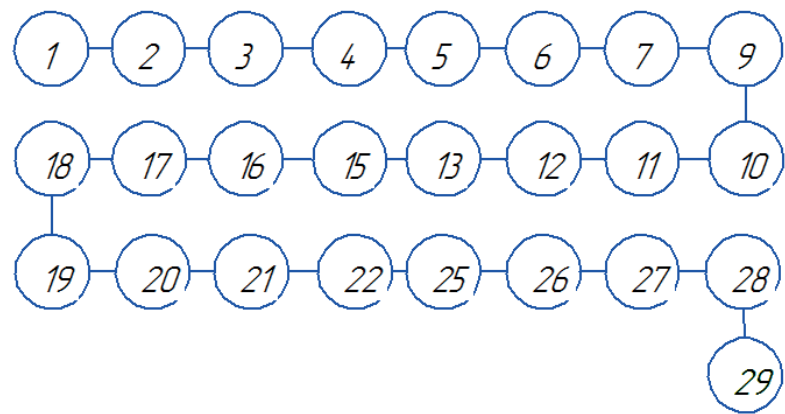

Figure 7 The sequence of operations as per scheme 7

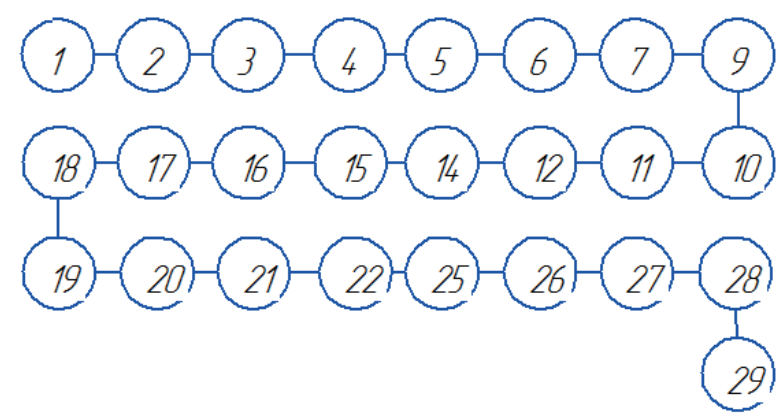

Figure 8 The sequence of operations as per scheme 8

from the port is done by the motor transport, an unloading of containers from the vehicle and unloading the cargo is organized.

The difference between the second scheme (Figure 2) from the first (Figure 1) is that the enterprise has its own containers, the transportation to the port comes over the rail transport, vehicles are rented from partner firms, the transportation from the port - by the rail transport, cargo from the containers is not unloaded, and immediately transferred to the recipient (Figure 2).

Alternatively, to the second in the third scheme (Figure 3), the transportation of the cargo to the port is carried out by auto transport, and the transportation from the port - by the rail one.

In the following scheme (Figure 4), the transportation of the cargo to the port is carried out by the rail transport and the transportation from the port - by the automotive one.

The main feature of the scheme (Figure 5) is the combination of the auto and rail transports during the transportation of containers to the port and from the port and cargo unloading outside containers at the transfer to the recipient.

The combination of the rail and auto transport in the process of bringing containers to the port and bringing them off the port is shown in scheme six (Figure 6).

The following combinations of operations are displayed in the scheme (Figures 7-10): combining types of transport, availability of own or rental vehicles, loading and unloading mechanisms, storing containers at the terminal or immediate reloading them into vehicles, transferring to the recipient of the cargo, unloaded from containers or transfer of downloaded containers.

The costs are the most important parameter when choosing the best option for the scheme of service orders when organizing the container cargo delivery in international connections [16]. For this reason, the following research develops a logistic approach to choosing a sequence of operations of the order service scheme, which would provide an opportunity to evaluate and optimize

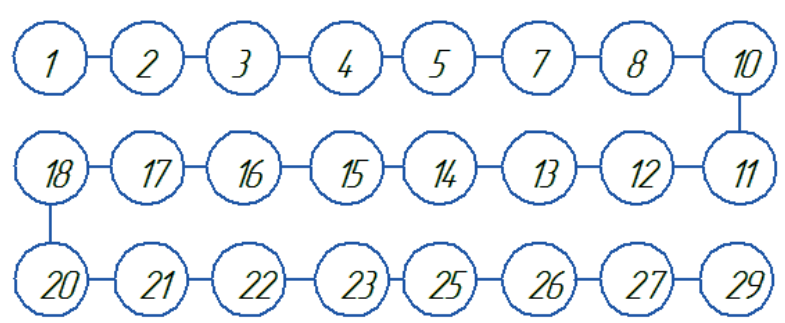

Figure 9 The sequence of operations as per scheme 9

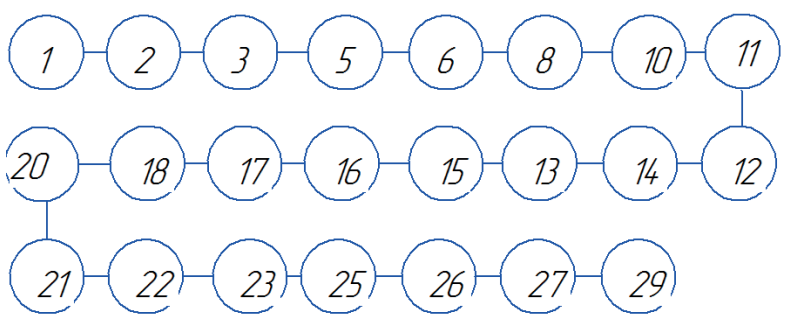

Figure 10 The sequence of operations as per scheme 10

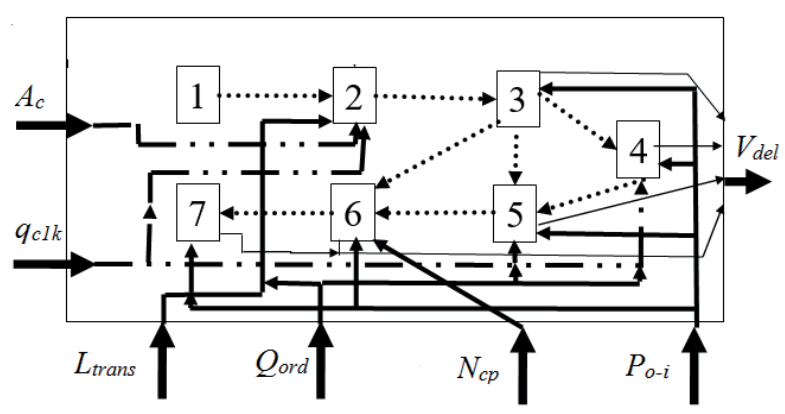

Figure 11 Schematic of displaying the proposed methodology of the logistic approach to the transportation system based on the cybernetic model "white box"

the associated costs of time, resources and funds. The limited resources in the delivery system have been considered, as well.

The use of models in this case requires not only their theoretical development, but the experimental verification on actual materials, as well. The process of processing orders in the organization of the container cargo delivery in international liaison is considered as a complex system, which has a complex of interconnected and interacting subsystems. For a more complete and accurate characteristics of the research object, a schematic representation of the logistic approach, based on the "white box", has been proposed (Figure 11).

This scheme clearly indicates which parameters significantly affect the object of the study and how they are interrelated. [25-26]. The adaptation of the cybernetic model "white box" is based on the four established types of connections between the groups of major processes and the main factors that have been formed in the proposed method, namely: between groups of main processes (1-7); between input parameters $\left(A_{\mathcal{c}} q_{c l k}\right)$ and groups of main processes (1-7); between groups of main processes (1-7) and output parameters $\left(V_{d e l}\right)$; between groups of main processes (1-7) and environmental factors $\left(L_{\text {trans }}, Q_{o r g}, N_{c p}, P_{o-i}\right)$. The scheme of Figure 2 shows the main processes that occur in organization of containers goods delivery in the international traffic of the company "Inter Trans Logistic": 1 - acceptance of the application for transportation; 2 - evaluation of the company's capabilities for application and choice of service order scheme; 3 - registration 
of documents; 4 - loading and unloading work with a cargo; 5 loading and unloading operations with the container; 6 - customs operations; 7 - moving the container.

\section{Results}

The input parameters that influence the process of container cargo transportation in international traffic are: number of containers $A_{c}$; nominal capacity of one container $q_{c 1 k}$. External factors are: distance transportation $L_{\text {trans }}$; volume of one order $Q_{\text {ord }}$; number of customs points $N_{c p}$; costs of a particular transaction $P_{o-i}$. As a starting point, from the logistic point of view, the total shipping costs have been chosen $V_{d e l}$, as well.

The system constraints, derived from the analysis of order "Agricultural Holding August", which establishes trade and economic ties with partners from Turkey, Italy, Spain, France and the UK for transportation of established packaged rape seeds, 10 tons of corn on demand and part of 20,000 liters of sunflower seeds oil and the possibilities regarding this order of the transport and logistics company "Inter Trans Logistic" have the following form:

$$
\left\{\begin{array}{l}
1 \leq A_{c} \leq 2 \\
10 \leq q_{c l k} \leq 30 \\
1000 \leq A_{c} \leq 9000 \\
10 \leq Q_{\text {ord }} \leq 30 \\
2 \leq N_{c p} \leq 6 \\
5 \leq P_{o-i} \leq 100
\end{array}\right.
$$

As a target function for the logistic approach to the transportation system based on the cybernetic model «white box», the function of the total costs of the cargo delivery from a set of parameters and factors has been chosen. Under such conditions, the target costs function should go to its minimum:

$V_{\text {del }}=f\left(A_{c}, q_{c 1 k}, L_{\text {trans }}, Q_{\text {ord }}, N_{c p}, P_{o-i}\right) \rightarrow \min$.

For further numerical calculation it is necessary to evaluate the input parameters and factors of the environment in the economic equivalent, namely, in the form of freight costs, consisting of a number of components:

$V_{d e l}=V_{l . u . w}+V_{t r a n s}+V_{c . d}+V_{c}+V_{c . s}+V_{d o c}$,

where $V_{\text {lu.w. }}$ - loading and unloading costs, US\$; $V_{\text {trans }}$-transportation costs, US\$; $V_{c . d}$ - costs of cargo customs declaration, US\$; $V_{c}$ rental costs of vehicles, containers, US\$; $V_{c . s}$ - costs of contractor services, US\$; $V_{d o c}$ - registration costs of financial-payment, commodity-accompanying documents, US\$.

Economic indicators, in the form of costs for specific operations, according to the proposed methodology of the logistic approach to the system of transportation based on the cybernetic model «white box» (Figure 12), have been estimated in stages according to the rates of transport operations of the company «Inter Trans Logistic».

As costs of loading and unloading operations are related to the cargo and containers, they can be calculated by the formula:
$V_{\text {l.u.w }}=V_{\text {l.cargo }}+V_{\text {l.cont }}+V_{\text {u.cont }}+V_{\text {u.cargo }}$,

where $V_{\text {l.cargo }}$ - costs of loading the container cargo, US\$; $V_{\text {l.cont }}$ costs of loading the cargo container in a vehicle, US\$; $V_{u \text { cont }}$ - costs of unloading the container from the vehicle, US\$; $V_{\text {u.cargo }}$ - costs of unloading the cargo from the container, US\$.

The costs of loading and unloading the container by cargo are the following:

$V_{l .(u .) \text { cargo }}=Q_{\text {ord }} \cdot C_{l . u}^{\text {cargo }}$.

In formula (5) there are costs of loading or unloading the cargo to / from one container, US\$/t.

The costs of loading and unloading the container in / out of the vehicle are:

$V_{l .(u .) \text { cont }}=A_{c} \cdot C_{l . u}^{c o n t}$.

In formula (6), the loading or unloading costs per container are given in US\$/unit.

The costs of transportation of containers by different modes of transport are the following:

$V_{\text {trans }}=V_{\text {w.cargo }}+V_{A T}+V_{R W}+V_{S T}$,

where $V_{\text {w.cargo }}$ - costs of mileage vehicle unladed, US\$; $V_{A T}$ - costs of transportation by road, US\$; $V_{R W}$ - transportation costs by rail, US\$; $V_{S T}$ - costs of transportation by sea, US\$.

It is worth saying that the costs of mileage vehicle unladed have been determined by taking into account the costs of moving a car per one kilometer and the corresponding distance.

The costs of transportation by the road, rail or sea are:

$V_{A T(R W, S T)}=Q_{\text {ord }} \cdot L_{\text {trans }}^{A T(R W, S T)} \cdot C_{\text {trans }}^{A T(R W, S T)}$,

where $L_{\text {trans }}^{A T(R W, S T)}$ - the distance of transportation by the appropriate type of transport; $C_{\text {trans }}^{A T(R W, S T)}$ - transportation costs per one ton-kilometer by the road, rail or sea.

The costs of the cargo customs declaration have been determined by taking into account the time of delay at the customs office $t_{t i}$ and the cargo delaying costs per one hour at the border office $C_{t . i}$ :

$V_{c . d}=t_{t . i} \cdot C_{t . i} \cdot N_{c p}$.

Rental costs of vehicles, containers are:

$V_{c}=A_{c} \cdot C_{c}$,

where $C_{c}$-rental costs of one vehicle (container) per day is defined as the average market in the territory of Ukraine.

The costs of contractor services $V_{c . s}$ take into account costs of brokerage agency services $C_{b r}$, the cargo insurance costs $C_{i n s}$ and the security services costs $C_{\text {sec }}$ :

$V_{c . s}=Q_{o r d} \cdot\left(C_{b r}+C_{i n s}+C_{\mathrm{sec}}\right)$ 


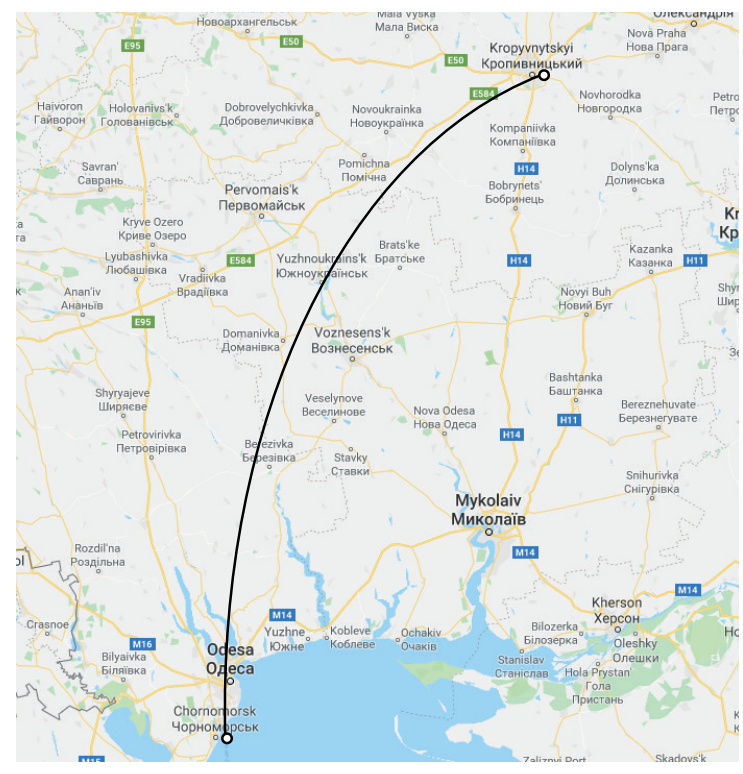

(a)

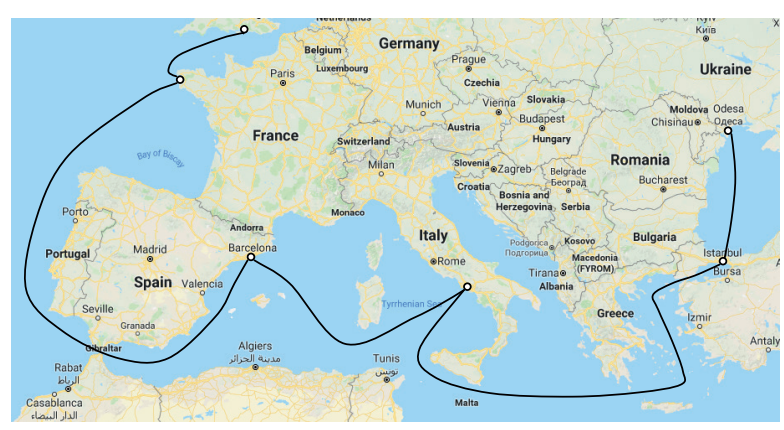

(b)

Figure 12 Schemes of container transportations by the company "Inter Trans Logistic" in accordance with the orders of the company "Agricultural Holding August" on the territory of Ukraine (a) and on the international traffic (b)

Table 1 Levels of factors variation

\begin{tabular}{ccc}
\hline Parameter & Minimum value & Maximum value \\
\hline Number of customs offices, pcs & 2 & 6 \\
Distance transportation, km & 2000 & 10000 \\
Volume of one order, t & 10 & 30 \\
The costs of a particular operation (service), US\$ & 5 & 100 \\
\hline
\end{tabular}

Table 2 Results of the experiment plan with allowance for the limit values

\begin{tabular}{|c|c|c|c|c|}
\hline \multirow{2}{*}{$\begin{array}{l}\text { A series of } \\
\text { experiments }\end{array}$} & \multicolumn{4}{|c|}{ Levels of variation } \\
\hline & Number of customs offices, pcs & Distance transportation, $\mathrm{km}$ & Volume of one order, $t$ & $\begin{array}{l}\text { The costs of a particular operation } \\
\text { (service), US\$ }\end{array}$ \\
\hline 1 & 6 & 10000 & 30 & 5 \\
\hline 2 & 6 & 10000 & 10 & 5 \\
\hline 3 & 6 & 2000 & 10 & 5 \\
\hline 4 & 2 & 10000 & 30 & 100 \\
\hline 5 & 2 & 2000 & 30 & 100 \\
\hline 6 & 2 & 2000 & 10 & 100 \\
\hline 7 & 2 & 10000 & 10 & 100 \\
\hline 8 & 6 & 2000 & 30 & 5 \\
\hline 9 & 2 & 2000 & 10 & 5 \\
\hline 10 & 6 & 10000 & 30 & 100 \\
\hline 11 & 6 & 2000 & 10 & 100 \\
\hline 12 & 6 & 2000 & 30 & 100 \\
\hline 13 & 2 & 10000 & 30 & 5 \\
\hline 14 & 6 & 10000 & 10 & 100 \\
\hline 15 & 2 & 2000 & 30 & 5 \\
\hline 16 & 2 & 10000 & 10 & 5 \\
\hline
\end{tabular}


Table 3 The calculation results of total costs for the international cargo container delivery for ten alternative service orders

\begin{tabular}{ccccccccccc}
\hline \multirow{2}{*}{$\begin{array}{c}\text { Series of } \\
\text { experiment }\end{array}$} & \multicolumn{7}{c}{ Total costs of cargo delivery, US\$ } \\
\cline { 2 - 11 } & Scheme 1 & Scheme 2 & Scheme 3 & Scheme 4 & Scheme 5 & Scheme 6 & Scheme 7 & Scheme 8 & Scheme 9 & Scheme 10 \\
\hline 1 & 7455.41 & 6338.74 & 6588.74 & 6644.29 & 7144.29 & 7210.96 & 7262.81 & 7151.70 & 6649.85 & 6714.67 \\
2 & 2377.63 & 2075.78 & 2159.11 & 2177.63 & 2251.70 & 2273.92 & 2292.44 & 2255.41 & 2179.48 & 2199.85 \\
3 & 851.70 & 586.89 & 623.92 & 698.00 & 723.92 & 786.89 & 779.48 & 720.22 & 629.48 & 677.63 \\
4 & 7452.42 & 6335.75 & 6585.75 & 6641.31 & 7141.31 & 7207.97 & 7259.83 & 7148.72 & 6646.86 & 6711.68 \\
5 & 2874.64 & 1869.09 & 1980.20 & 2202.42 & 2557.97 & 2746.86 & 2720.94 & 2543.16 & 1996.86 & 2145.01 \\
6 & 848.72 & 583.90 & 620.94 & 695.01 & 720.94 & 783.90 & 776.49 & 717.23 & 626.49 & 674.64 \\
7 & 2374.64 & 2072.79 & 2156.12 & 2174.64 & 2248.72 & 2270.94 & 2289.46 & 2252.42 & 2176.49 & 2196.86 \\
8 & 2877.63 & 1872.07 & 1983.18 & 2205.41 & 2560.96 & 2749.85 & 2723.92 & 2546.15 & 1999.85 & 2148.00 \\
9 & 848.72 & 583.90 & 620.94 & 695.01 & 720.94 & 783.90 & 776.49 & 717.23 & 626.49 & 674.64 \\
10 & 7455.41 & 6338.74 & 6588.74 & 6644.29 & 7144.29 & 7210.96 & 7262.81 & 7151.70 & 6649.85 & 6714.67 \\
11 & 851.70 & 586.89 & 623.92 & 698.00 & 723.92 & 786.89 & 779.48 & 720.22 & 629.48 & 677.63 \\
12 & 2877.63 & 1872.07 & 1983.18 & 2205.41 & 2560.96 & 2749.85 & 2723.92 & 2546.15 & 1999.85 & 2148.00 \\
13 & 7452.42 & 6335.75 & 6585.75 & 6641.31 & 7141.31 & 7207.97 & 7259.83 & 7148.72 & 6646.86 & 6711.68 \\
14 & 2377.63 & 2075.78 & 2159.11 & 2177.63 & 2251.70 & 2273.92 & 2292.44 & 2255.41 & 2179.48 & 2199.85 \\
15 & 2874.64 & 1869.09 & 1980.20 & 2202.42 & 2557.97 & 2746.86 & 2720.94 & 2543.16 & 1996.86 & 2145.01 \\
16 & 2374.64 & 2072.79 & 2156.12 & 2174.64 & 2248.72 & 2270.94 & 2289.46 & 2252.42 & 2176.49 & 2196.86 \\
\hline
\end{tabular}

The registration costs of financial-payment, commodityaccompanying documents are:

$$
V_{d o c}=\sum_{j=1}^{k} C_{r e g j} \cdot n_{r j}
$$

Equation (12) takes into account the costs of processing documents $\mathrm{k}$ of type $C_{\text {regi }}$ and the number of documents of the appropriate destination $n_{r i^{*}}$

The method of mathematical planning experiment has been used to implement the developed methodology of the logistic approach to the efficient organization of the container cargo transportation. To this end, a plan of a full-factor experiment has been prepared due to four external factors: the distance of transportation, the volume of one order, the number of customs offices, the costs of a particular operation, the minimum and maximum value of which is determined by the system of restrictions Equation (2) between Ukraine and the European Union countries (Table 1). In forming levels of varying factors that affect goods transportation cost in international connections, it is necessary to set the maximum values that will correspond to the order of the company "Agricultural Holding August" by transporting the cargo by "Inter Trans Logistic" company. The number of customs offices has been taken into account, which can maximally affect the transport costs. The minimum number will be 2 (initial and final), and the maximum number -6 points for international traffic in relation to the application of the company "Agricultural Holding August" and the established route of rice 3. The volume levels of orders have been formed from firm applications. Costs of operations (services) are reflected in the unit derived from the analysis of costing services company "Inter Trans Logistic".

For given factors, the number of experiments series is 16 . As 2 levels of variation has been chosen, so designate them as follows: "." - 1st level of variation (min), "+" - level 2 (max). After that, all possible combinations of connections and values have been tabulated in Table 2.

Calculations of total costs in the studied ten schemes have been made in Microsoft Excel, and the results are shown in Table 3.

\section{Discussion}

To substantiate the developed methodology of the logistic approach for choosing a rational technology for servicing orders for international container transportation of goods and e influence of parameters on the criterion of their efficiency (expenses), a regression analysis has been chosen. Among the investigated factors, the following connections have been considered: linear function with nonzero coefficient; linear function with zero coefficient; power function with nonzero coefficient; power function with zero coefficient. To construct the model, the Microsoft Excel program was used, which employs a program for calculating regression mathematical models. Using the above-mentioned cases of analytic regression functions, a regression analysis has been performed for each alternative order service (Figures 1-10). It has been determined that for each operation scheme (Figures 1-10) the linear function with a non-zero coefficient is the best, because in that case the value of determination coefficient $\mathrm{R}$ is maximum and equals to 0.9 . The regression coefficients have been estimated by: the standard error; the meaning of "t-statistics"; "P-value"; significant indicators. According to results of this assessment, factors such as the number of customs offices and the price of a particular operation have not been taken into account in the mathematical model of costs. Thus, the general formula of the regression model of costs is the following

$V_{d e l}^{m}=a_{0}+a_{1} \cdot L_{\text {trans }}+a_{2} \cdot Q_{\text {ord }}$, 
Table 4 Determination results of regression models unknown coefficients

\begin{tabular}{ccccccccccc}
\hline \multirow{2}{*}{ Indicator } & \multicolumn{7}{c}{ The value of unknown coefficients of regression models for the corresponding schemes } \\
\cline { 2 - 10 } & Scheme 1 & Scheme 2 & Scheme 3 & Scheme 4 & Scheme 5 & Scheme 6 & Scheme 7 & Scheme 8 & Scheme 9 & Scheme 10 \\
\hline$a_{1}$ & -2254 & -2293 & -2262 & -2279 & -2490 & -2429 & -2466 & -2500 & -2385 & -2345 \\
$a_{2}$ & 0.52 & 0.48 & 0.48 & 0.47 & 0.48 & 0.46 & 0.48 & 0.48 & 0.49 & 0.48 \\
$a_{3}$ & 197.6 & 158.7 & 164.7 & 169.4 & 178.2 & 182.5 & 182.9 & 178.1 & 166.1 & 159.6 \\
\hline
\end{tabular}

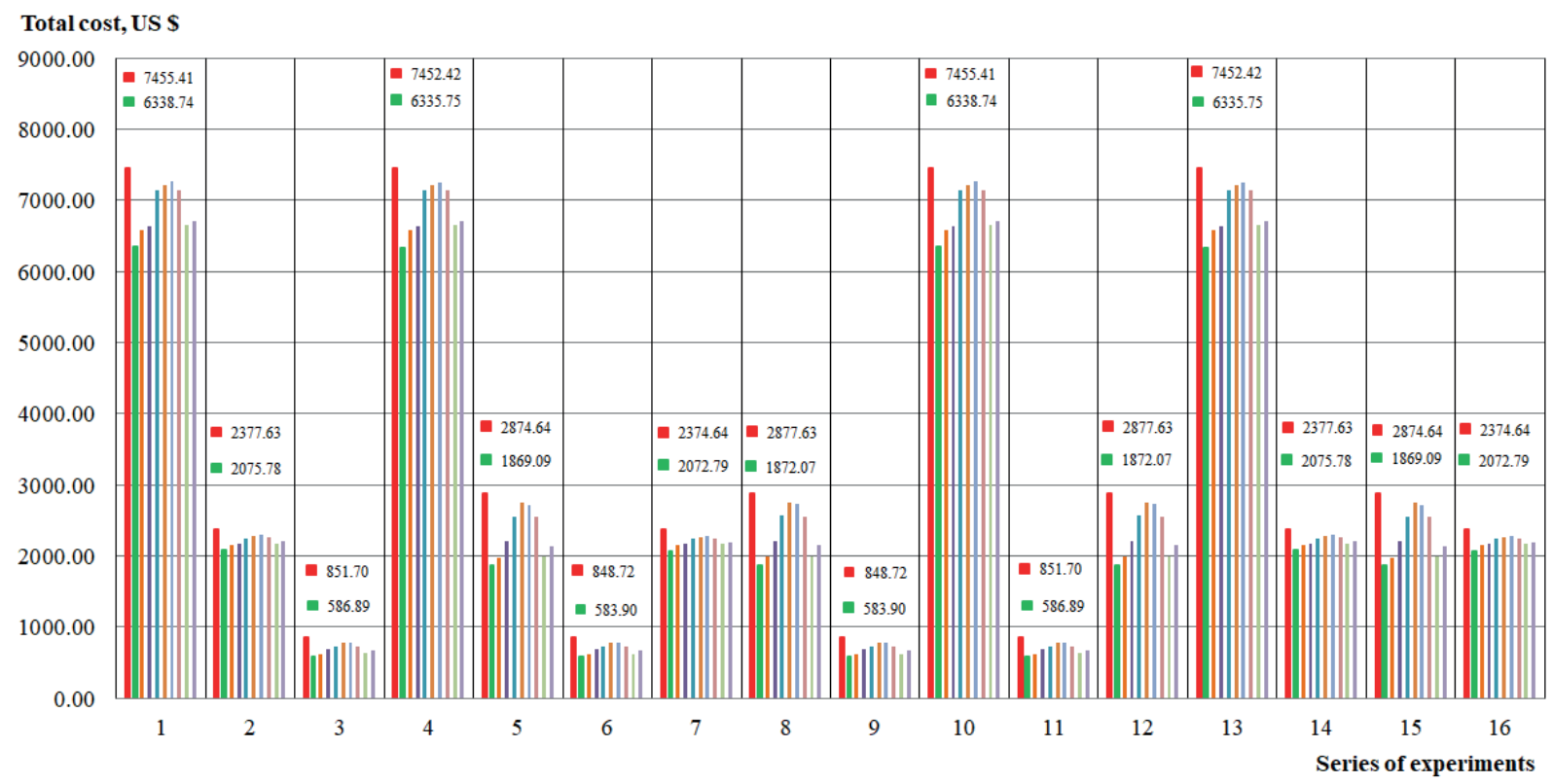

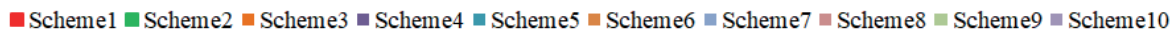

Figure 13 Total costs for international container delivery according to a series of experiment planning experiments indicating the maximum and minimum costs of the developed transport order schemes

where $m$ - the number of the corresponding order service scheme, $a_{0}, a_{1}, a_{2}$ - unknown coefficients of the regression equation $L_{\text {trans }}$, $Q_{\text {ord }}$. Results of determining the coefficients of regression (13) have been presented in Table 4. According to the mathematical model for the ten service schemes, the calculated values of expenditure have been calculated and are presented in the form of a graph in Figure 13.

With implementation of the container delivery company "Inter Trans Logistic", order service company "Agricultural Holding August" for the transportation of rape seeds, 10 tons of corn on demand and a portion of sunflower oil is 20,000 liters, according to the applications have been systematized in Table 1 . From the analysis of the graphic representation of the total cost of international container delivery of the goods of the customer firm (Figure 13), it follows that the maximum costs will be according to the scheme of order maintenance. In this case, the costs have been in the range of 848.72 to 7455.41 US \$, according to a certain series of experiments. Proceeding from condition (2) and analysis of the data presented in Figure 13, scheme 1 has been selected for the marginal order maintenance service, concerning which the estimation of change of general expenses at realization of other schemes has been carried out. In percentage display according to Scheme 1, the following intervals have been received: reduction of expenses for the implementation of the order: scheme $2-12.70$ to $34.98 \%$; Scheme $3-2.93$ to $12.00 \%$; Scheme $4-2.06$ to $10.88 \%$; Scheme $5-1.69$ to $4.25 \%$; Scheme $6-0.87$ to $3.28 \%$; scheme
7 - 0.97 to $2.58 \%$; Scheme 8 - 1.64 to $4.45 \%$; Scheme 9 - 2.66 to $11.77 \%$; scheme $10-2.33$ to $9.94 \%$

Results of experimental studies indicate that when the proposed methodology of the logistic approach, using the "white box", to international container transportation of goods in relation to the application for transportation, the scheme 2 sequence of transport operations has been effective. In its realization, the costs have been decreased for 12.70 to $34.98 \%$ in comparison to the marginal service scheme 1 .

In the future it is planned to build based on the obtained results an imitation model based on the developed methodology and models in the environment of Petri Networks taking into account the risk factors at each stage of the process of the container delivery of goods in international traffic.

\section{Conclusions}

- It has been revealed that the proposed method of logistic approach to the container transportation system, based on the cybernetic model of the "white box" allows to take into account in more detail, form the possibilities of the transport and logistics enterprise in relation to the order and effectively choose the order of the service maintenance with the minimum expenses for carrying out transportation. 
- Using the logistic approach to the container transport system, based on the cybernetic model of the "white box", based on the company "Inter Trans Logistic", serving the order of the company "Agricultural Holding August" for the transportation of packaged rape seeds, 10 tons of corn on demand and part of 20,000 liters of sunflower seeds oil, according to applications, maximum expenses 848.72 to 7455.41 US $\$$ have been received according to scheme 1 of service of this order.
- Results analysis of experimental studies of changes in costs during the transportation, at the request of the firm "Agricultural Holding August", indicates that an efficient scheme of transport operations has been Scheme 2, because at the same time costs of 12.70 to $34.98 \%$ have been reduced in comparison with the limit scheme 1 of the transport order service by the company "Inter Trans Logistic".

\section{References}

[1] SKOROBOGATOVA, O., KUZMINA-MERLINO, I. Transport infrastructure development performance. Procedia Engineering [online]. 2017, 178, p. 319-329. ISSN 1877-7058. Available from: https://doi.org/10.1016/j.proeng.2017.01.056

[2] LORD, J. D. Retail saturation: Inevitable or irrelevant? Urban Geography [online]. 2000, 21(4), p. 342-360. ISSN 0272-3638/eISSN 1938-2847. Available from: https://doi.org/10.2747/0272-3638.21.4.342

[3] WANG, T., CULLINANE, K. The efficiency of European container terminals and implications for supply chain management. In: Haralambides H.E. (eds) Port Management [online]. London: Palgrave Readers in Economics, Palgrave Macmillan, 2015, p. 253272. ISBN 978-1-137-47576-3/e ISBN 978-1-137-47577-0. Available from: https://doi.org/10.1057/9781137475770_12

[4] RYZHENKOVA, N.: Containers market overview in Ukrainian ports in the first half of 2017. Ports of Ukraine [online]. [Viewed 2017-09-25]. Available from: https://ports.com.ua/articles/obzor-rynka-konteynerov-v-portakh-ukrainy-v-i-polugodii-2017

[5] LIU, H. B., et al. A study on operational model of container multi-modal transport virtual enterprise based on multi-agent technology. Advanced Materials Research [online]. 2015, 1065-1069, p. 3310-3313. ISSN 1662-8985/eISSN 1662-8985. Available from: https://doi.org/10.4028/www.scientific.net/AMR.1065-1069.3310

[6] LI, B., WU, C. W., CAO, J. X. The integrated optimization of container port logistics system resources. Applied Mechanics and Materials [online]. 2014, 505-506, p. 878-883. ISSN 1662-7482/eISSN 1662-7482. Available from: https://doi.org/10.4028/www. scientific.net/AMM.505-506.878

[7] QIAN, X. W. The application of SLP with Hungarian method in the spatial layout planning of logistics park-with Chengdu international railway container logistics park as an example. Advanced Materials Research [online]. 2014, 838-841, 1273-1280. ISSN 1662-8985/eISSN 1662-8985. Available from: https://doi.org/10.4028/www.scientific.net/AMR.838-841.1273

[8] CHOU, C. C., et al. Operation management of port logistics in the global supply chain. Advanced Materials Research [online]. 2013, 706-708, p. 2087-2090. ISSN 1662-8985/eISSN 1662-8985. Available from: https://doi.org/10.4028/www.scientific.net/AMR.706708.2087

[9] XU, C. X., JIANG, M. M., WANG, Z. Y. Contrast research on containers collecting and distributing system of Guangzhou port and Dalian port. Applied Mechanics and Materials [online]. 2012, 209-2011, p. 667-670. ISSN 1662-7482/eISSN 1662-7482. Available from: https://doi.org/10.4028/www.scientific.net/AMM.209-211.667

[10] ZHANG, X., SONG LIN, J., ZHAO, Z. Study of container transport planning model and algorithm. Advanced Materials Research [online]. 2013, 605-607, p. 570-573. ISSN 1662-8985/eISSN 1662-8985. Available from: https://doi.org/10.4028/www.scientific. net/AMR.605-607.570

[11] RUSGIYARTO, F., et al. Discrete event simulation model for external yard choice of import container terminal in a port buffer area. In 3rd International Conference on Engineering, Technology and Industrial Application : proceedings [online]. Vol. 1855(1), AIP Publishing, 2017. ISBN 978-0-7354-1529-4, p. 040014-1-040014-8. Available from: https://doi.org/10.1063/1.4985510

[12] ZHONG, W. Z., FU, X. Q., WANG, Y. P. Petri Net modeling: Container terminal production operation processing system analysis. Applied Mechanics and Materials [online]. 2013, 409-410, p. 1320-1324. ISSN 1662-7482/eISSN 1662-7482. Available from: https:// doi.org/10.4028/www.scientific.net/AMM.409-410.1320

[13] VADVARI, T., VARLAKI, P. Identification of supply chains based on input-output data. Periodica Polytechnica Transportation Engineering [online]. 2015, 43(3), p. 162-167. ISSN 0303-7800/eISSN 1587-3811. Available from: https://doi.org/10.3311/PPtr.7931

[14] PAVLENKO, O., VELYKODNYI, D. The choice of rational technology of delivery of grain cargoes in the containers in the international traffic. International Journal for Traffic and Transport Engineering [online]. 2017, 7(2), p. 164-176. ISSN 2217-544X/ eISSN 2217-5652. Available from: https://doi.org/10.7708/ijtte.2017.7(2).02

[15] CARLO, H., VIS, I., JANROODBERGEN, K.: Storage yard operations in container terminals: Literature overview, trends, and research directions. European Journal of Operational Research [online]. 2014, 235(2), p. 412-430. ISSN 0377-2217. Available from: https://doi.org/10.1016/j.ejor.2013.10.054

[16] AULIN, V., HOLUB, D. Regulatory and legal support transport systems functioning reliability in Ukraine. Journal of Zhytomyr State Technological University. Technical Sciences Series. 2016, 2(77), p. 28-35. ISSN 1728-4260/eISSN 2522-1779. 
[17] AULIN, V., et al. Substantiation of diagnostic parameters for determining the technical condition of transmission assemblies in trucks. Eastern European Journal of Enterprise Technologies [online]. 2018, 2(1), p. 4-13. ISSN 1729-3774/eISSN 1729-4061. Available from: https://doi.org/10.15587/1729-4061.2018.125349

[18] NOJIRI, W., KANEKO, J., FUJIWARA, T. Long-distance Transportation of automotive parts by third-party logistics providers from the viewpoint of spatial organization of just-in-time systems. Geographical Review of Japan [online]. 2012, 85(1), p. 1-21. ISSN 1883-4388/eISSN 2185-1751. Available from: https://doi.org/10.4157/grj.85.1

[19] ISO/IEC/IEEE 24765:2017 Systems and software engineering - Vocabulary [online]. Available from: https://www.iso.org/ standard/50518.html

[20] SEO, S. - H., et al. A security framework for a drone delivery service. In 2nd Workshop on Micro Aerial Vehicle Networks, Systems and Applications for Civilian Use Dro Net 16 : proceedings [online]. New York, NY, USA, ACM, 2016. ISBN 978-1-4503-4405-0, p. 29-34. Available from: https://doi.org/10.1145/2935620.2935629

[21] PETRASKA, A., et al. The algorithm for the assessment of heavyweight and oversize cargo transport routes. Journal of Business Economics and Management [online]. 2017, 18(6), p. 1098-1114. ISSN 1611-1699/eISSN 2029-4433. Available from: https://doi.org /10.3846/16111699.2017.1334229

[22] GAJEWSKA, T., ZIMON, D. Study of the logistics factors that Influence the development of e-commerce services in the customer's opinion. Archives of Transport [online]. 2018, 45(1), p. 25-34. ISSN 0866-9546/e-ISSN 2300-8830. Available from: https://doi.org/10.5604/01.3001.0012.0939

[23] AGBELIE, B. R. D. K. An empirical analysis of three econometric frameworks for evaluating economic impacts of transportation infrastructure expenditures across countries. Transport Policy [online]. 2014, 35, p. 304-310. ISSN 0967-070X. Available from: https://doi.org/10.1016/j.tranpol.2014.06.009

[24] ALGHAFFARI, S., NGUYEN, H., CHEN, P. Critical factors for organisational effectiveness: The case of Saudi Arabian seaports. Journal of Sustainable Development of Transport and Logistics [online]. 2018, 3(2), p. 49-65. eISSN 2520-2979. Available from: https://doi.org/10.14254/jsdt1.2018.3-2.3

[25] AULIN, V., et al. Studying truck transmission oils using the method of thermal-oxidative stability during vehicle operation. EasternEuropean Journal of Enterprise Technologies [online]. 2019, 1(6)(97), p. 6-12. ISSN 1729-3774/eISSN 1729-4061. Available from: https://doi.org/10.15587/1729-4061.2019.156150

[26] KRYVORUCHKO, O., SHYNKARENKO, V., POPOVA, N. Quality management of transport services: Concept, system approach, models of implementation. International Journal of Engineering and Technology (UAE) [online]. 2018, 7(4.3), p. $472-476$. eISSN 2227-524X. Available from: https://www.scopus.com/inward/record.uri?eid=2-s2.0-85056727889\&partnerID=40\&md5=bd 246aa071591c2 e9699888b3 d9bbd03 